\title{
Wear fretting behavior of thick HA anodizing alumina layer
}

\author{
A. Raid*, N. Boualem**, V. Fridrici***, Ph. Kapsa**** \\ *Mechanical Engineering Faculty, USTMB Oran, B.P 1505 El M'naouer, Oran, Algeria, E-mail: bousourai@yahoo.fr \\ **Mechanical Engineering Faculty, USTMB Oran, B.P1505El M'naouer, Oran, Algeria, \\ E-mail: nour_boualem@yahoo.fr \\ ***Laboratoire de Tribologie et Dynamique des Systèmes, UMR 5513, 36 Avenue Guy de Collongue, 69134 Ecully, \\ Cedex, France, E-mail: Vincent.Fridrici@ec-lyon.fr \\ ****Laboratoire de Tribologie et Dynamique des Systèmes, UMR 5513, 36 Avenue Guy de Collongue, 69134 Ecully, \\ Cedex, France, E-mail: Philippe.Kapsa@ec-lyon.fr
}

crossref http://dx.doi.org/10.5755/j01.mech.17.4.578

\section{Introduction}

Alumina layers formed by anodization of aluminium in an electrolyte had been studied and used in commercial processes over the last six decades [1]. There are two types of anodic alumina, the non porous barrier-type oxide and porous oxide, according to the nature of the electrolyte used. In this paper, two different types of anodizing were used to obtain porous alumina films, namely sulfuric anodisation (SA) and hard anodisation treatment (HA), which are widely used for protection against corrosion, decorative aspect and wear resistance.

The first step is to optimize parameters such as anodizing voltage, electrolyte concentration and temperature $[1,2]$. The second step is to investigate the effect of HA treatment on the tribological behavior. Based on the electric field distribution at the pore bottoms and the kinetics growth of porous alumina films formed by anodic oxidation, the resulting film morphology is controlled by the interplay between film growth and oxide dissolution [3].

Several works used thin films ranging from 18 to $20 \mu \mathrm{m}$ [4], 30 to $70 \mu \mathrm{m}$ for other authors [5] and $90 \mu \mathrm{m}$ with a two-step-procedure [6]. Well-ordered nanostructures formed by aluminium anodization in sulphuric acid have been noted, the resulting array of well-ordered nanopores depends strongly on anodizing potential applied voltage and temperature. In addition, the triangular lattice with highest density can be formed only in sulfuric acid [6].

There are few studies on the effect of thick layers in tribology, probably because layer thickness up to 100 $\mu \mathrm{m}$ is often described as being hard and accompanied by fragility risk [5]. Apart from the corrosion resistance, our work was focused on fretting wear behavior of boat superstructures assemblies made of 5000 aluminum family used in naval construction. The fretting is a complex process implying physical phenomena (abrasion, adhesion, ...) and chemical reactions which act on the surface. It is defined as an oscillatory movement of low amplitude taking place between two surfaces in contact which are subjected to cyclic vibrations or stresses. It concerns several branches of industry (aircraft, railways, boat superstructure, joint prostheses, bridge engineering cables, ...) $[7,8]$.

An new approach was introduced in order to represent and classify experimentally the fretting through fretting cards which consist in a diagram showing the various regimes according to parameters such as (displacement, amplitude and frequency) with their respective boundaries indicating the transition from one regime to another. The wear response of A357 aluminium alloy against AISI 52100 steel has been undertaken experimentally and modeling wear abrasive aspects of an A357 aluminium alloy under gross slip fretting conditions has been investigated [9-11]. Fretting loadings have been reproduced through a simple sphere/plane contact configuration. Fretting maps for anodized aluminium alloys of various surface modifications were established based on sliding transition criteria $[12,13]$.

The results confirm that fretting maps are effective tools to predict the fretting fatigue properties of substrates and coatings surface modification. The concept of the dissipated energy in wear analysis of hard coating has been used [14].

\section{Samples preparation}

Samples to anodize are cut out with ISOMET 4000 BUEHLER under lubrication. Dimensions of final samples are $3 \times 15 \times 100 \mathrm{~mm}^{3}$. We choose diluted solution $\mathrm{H}_{2} \mathrm{SO}_{4}(20 \%$ mass $)$ largely used in industry to obtain a hard layer. Fig. 1 shows an overview of the electrochemical cell used.

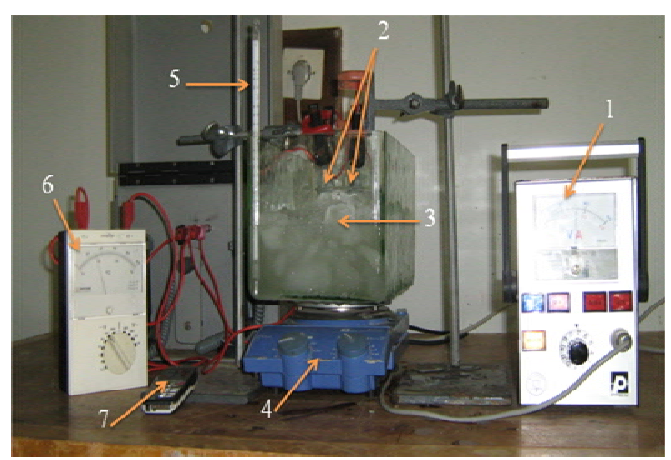

Fig. 1 Anodization device: 1 - current source, 2 - electrodes, 3 - cell immersed in ice, 4 - magnetic stirrer, 5 - thermometer, 6 - voltmeter, 7 - chronometer

The aluminum alloy used as substrate is the Al 5083 (Vickers Hardness $70 \mathrm{HV}$ ). It was provided in the form of coupons of $3 \mathrm{~mm}$ thickness. Before anodization, a surface polishing was carried out with abrasive papers, followed by a fine polishing with diamonds paste $(1 \mu \mathrm{m})$ and alumina $(0.4 \mu \mathrm{m})$ to reach a mirror state with a $0.1 \mu \mathrm{m}$ roughness. The samples are then degreased with methanol followed by an ultrasound bath during $15 \mathrm{mn}$. This surface treatment led in all the cases to a strong adhesion between 
the alumina layer and the substrate since the anodization process is not a simple deposit but a real growth phenomenon, result of a competition between a dissolution and a build of the layer on aluminium alloys $[4,5]$.

The bulk hardness of the materials was obtained using a Vickers hardness tester at an applied load of $10 \mathrm{~N}$ and the microhardness measurements on polished crosssection of the alumina layer were carried out using a Vickers microhardness tester at an applied load of $0.5 \mathrm{~N}$. The chemical composition of Al 5083 is given in Table 1 .

Table 1

Chemical composition of Al $5083 \mathrm{H} 111$ (mass \%)

\begin{tabular}{|c|c|c|c|c|c|c|c|}
\hline $\mathrm{Si}$ & $\mathrm{Fe}$ & $\mathrm{Cu}$ & $\mathrm{Mn}$ & $\mathrm{Mg}$ & $\mathrm{Cr}$ & $\mathrm{Zn}$ & $\mathrm{Ti}+\mathrm{Zr}$ \\
\hline $\mathrm{Max}$ & $\mathrm{Max}$ & $\mathrm{Max}$ & 0.40 & 4.00 & 0.05 & $\mathrm{Max}$ & $\mathrm{Max}$ \\
0.40 & 0.40 & 0.1 & 1.00 & 4.90 & 0.25 & 0.25 & 0.15 \\
\hline
\end{tabular}

The treatment of hard anodization (HA) was carried out following different steps: preparing a new solution at each anodizing (200 g/l, sulphuric acid). In the anodization cell with magnetic stirrer, an acid solution is surrounded by a bath with ice at $0^{\circ} \mathrm{C}$, in which two electrodes, aluminum and carbon plates are positioned at $15 \mathrm{~mm}$. The positive pole $(+)$ of the generator is connected to aluminum and the negative pole (-) to the carbon. The potential increases with progressive rise to the final stage $30 \mathrm{~V}$. However, it is very important to maintain the solution at ranged temperature 0 to $5^{\circ} \mathrm{C}$ during anodizing to evacuate heat for HA treatment. This step allows the use of high current density up to $3 \mathrm{~A} / \mathrm{dm}^{2}$ which permits to reach greater thicknesses in the range of 50 to $150 \mu \mathrm{m}$ and remaining within the operation limits to avoid burns.

Fig. 2 shows a micrographic cut of hard anodized Al 5083 sample. We can see that the layer thickness of $115 \mu \mathrm{m}$ is uniform, continuous and compact.

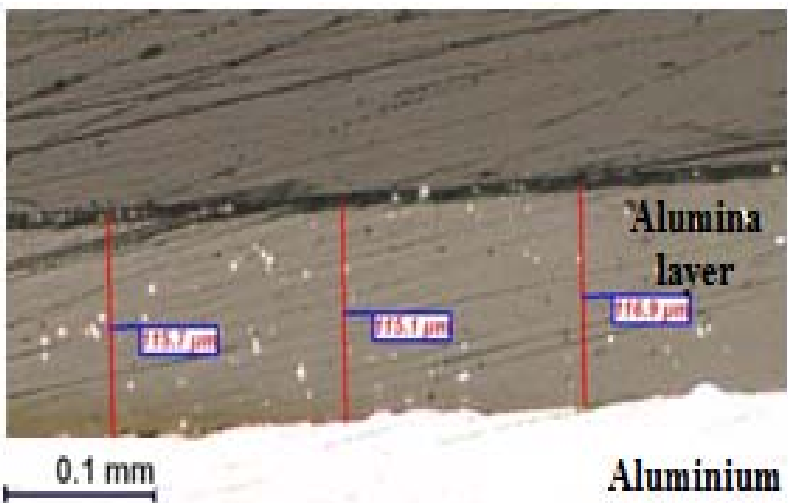

Fig. 2 Optical observation of alumina layer (HA treatment, potential $27 \mathrm{~V}$, duration $240 \mathrm{mn}$ )

This very thick layer presents a hardness profile which value is double from $\mathrm{Al} / \mathrm{Al}_{2} \mathrm{O}_{3}$ interface to the surface (Fig. 3). The layer measured roughness parameters, $\mathrm{Ra}$, Rt and Rq (average roughness, peak-to-valley average maximum height and root mean square roughness) are gathered in Table 2.

Table 2

Mean and maximal roughness of the sample

\begin{tabular}{|c|c|c|}
\hline $\mathrm{Ra}, \mu \mathrm{m}$ & $\mathrm{Rt}, \mu \mathrm{m}$ & $\mathrm{Rq}, \mu \mathrm{m}$ \\
\hline 0.76 & 4.14 & 0.94 \\
\hline
\end{tabular}

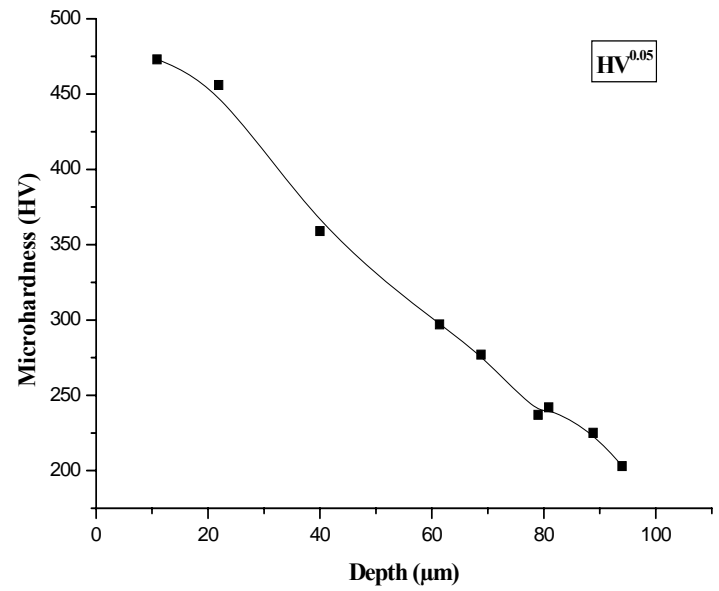

Fig. 3 Microhardness profile of thick hard anodic layer

\section{Wear tests and discussion}

The fretting tests are carried out on a hydraulic machine traction and compression. The studied configuration is a sphere-plan contact (Fig. 4). The sphere material was AISI 52100 steel ball bearing $(E=210 \mathrm{GPa}, v=0.3$ and $R=12.7 \mathrm{~mm}$ ) constitutes the fixed part (1) and the covered sample (2) is subjected to small amplitudes vibrations. The normal force is maintained constant while the tangential force and displacements are measured respectively by a sensor and an extensometer, all the data are transmitted to a computer. The tests are carried out in the air at room temperature of the laboratory with a relative humidity ranging from 35 to $50 \%$. To quantify wear, we studied the effect of the displacement amplitude $( \pm 15, \pm 25$ and $\pm 40 \mu \mathrm{m})$ under large slip regime conditions at a constant normal load of $150 \mathrm{~N}$ for three cycle numbers 10000 , 20000 and 50000 respectively, with a constant frequency of $5 \mathrm{~Hz}$.

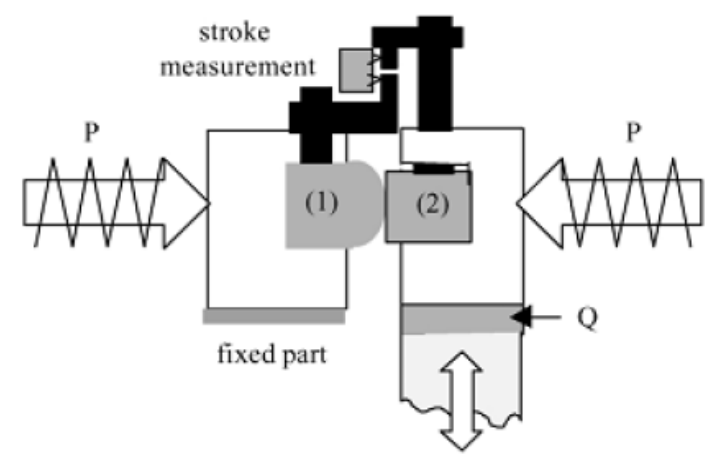

imposed stroke

Fig. 4 Simplified schematic illustration of the fretting test [10] by Fig. 5 .

The three principal fretting modes are represented

1. The partial slip regime (PSR) is defined by a cycle, tangential forces according to displacement, completely closed. It is characterized by a regime almost no dissipative.

2. The large slip regime (GSR) is characterized by quasi-rectangular cycles.

3. The mixed regime (MSR) is characterized by a complex form: closed, quasi-rectangular generally finishing by an ellipse after a certain time. 
The application of the transition criteria (heterogeneous contact: steel against alumina) with parameters values $(E, v)$ of the studied materials gives: $\beta=0.0066<$ $<0.21$ and $\gamma=0.0232<0.06$ for a friction coefficient $\mu=1.1$ [10-12]. Cycles shape remains quasi-rectangular with small variations of the maximum tangential load at the end of each cycle (Fig. 6, a), which means that we are under large slip mode.
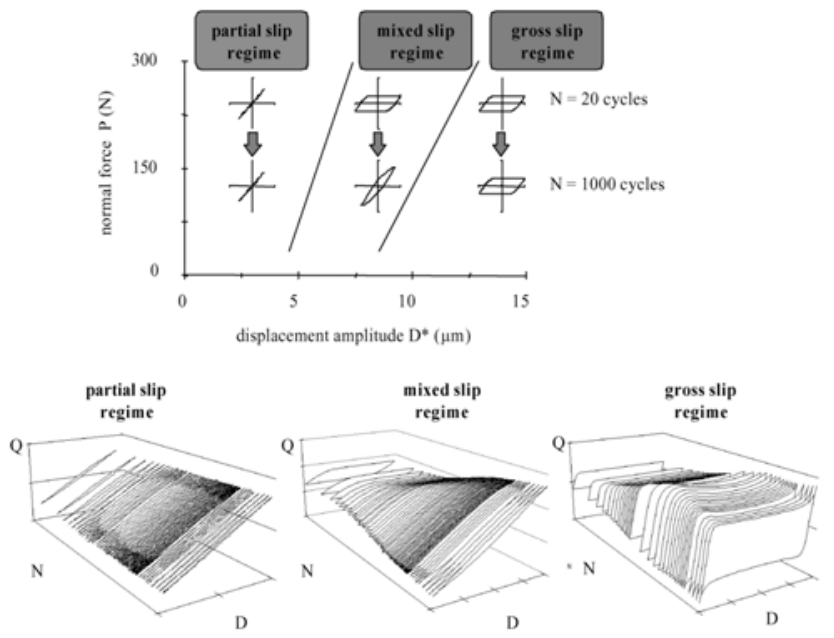

Fig. 5 Definition of fretting regimes [13]

Various important parameters are defined in literature: $Q^{*}, \delta_{g}$ and $E_{d}$ the dissipated energy in wear (hysteresis area) [14]. Fig. 6, b illustrates the scar and fretting debris as like-flakes on the layer alumina when opening the contact $\left(\mathrm{Al}_{2} \mathrm{O}_{3}, \mathrm{Fe}_{2} \mathrm{O}_{3}, \ldots\right)$.

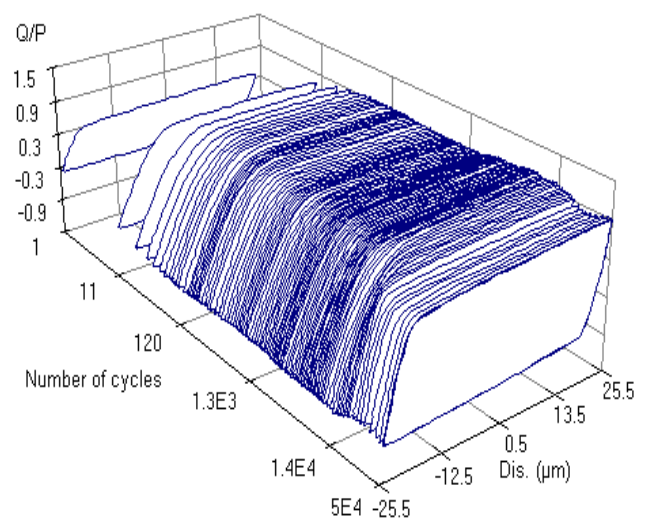

a

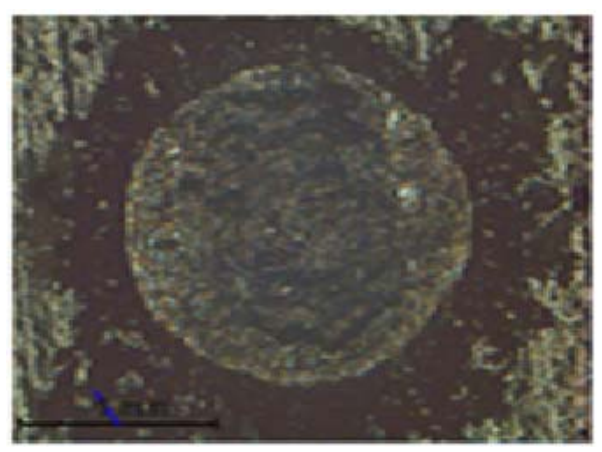

b

Fig. 6 a) illustration of gross slip fretting regime for the displacement of $\pm 25 \mu \mathrm{m}$ and cycle number of 50000 ; b) optical observation of the fretting scar
Fig. 7 represents wear coefficient histogram for the normal force of $150 \mathrm{~N}$ with displacement values of 10,25 and $40 \mu \mathrm{m}$ respectively at cycle number of 10000, 20000 and 50000 . We can clearly note that the average friction coefficient is close to 1.1. This indicates severe wear conditions of the tribological system between the contact of the AISI 52100 sphere steel and the very hard alumina layer.

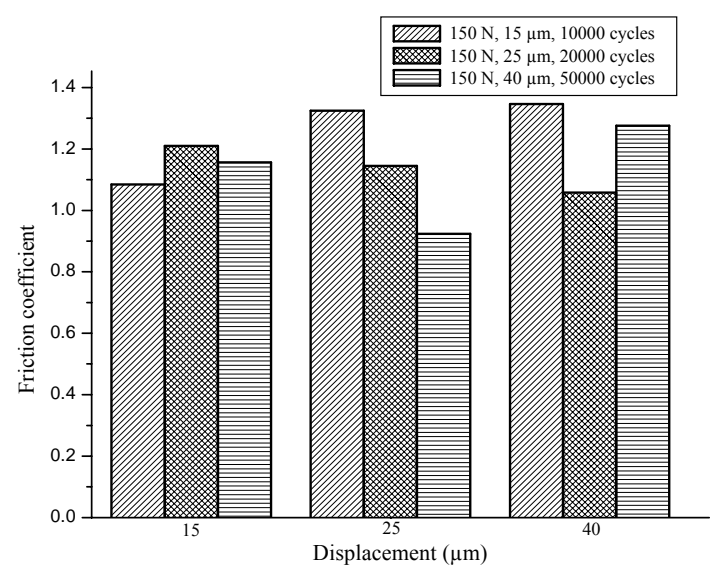

Fig. 7 Friction coefficient histogram according to $150 \mathrm{~N}$ force for various displacements and different cycle number

In Fig 8, we can note that for the same value of the normal force $(150 \mathrm{~N})$, wear increases quickly with the cycle number (10000 and 20000 cycles) and displacement $(15,25$ and $40 \mu \mathrm{m})$ practically with the same variation, whereas for a higher cycle number (50000 cycles), i.e. corresponding to more important test duration, the variation of wear tends to stabilize. The role of debris in the tribological phenomena as lubricant attenuating wear is well established. For lower cycle number, we note that debris are easily evacuated [15]. For the normal load of $150 \mathrm{~N}$, the Hertz theory gives a scar radius of $553 \mu \mathrm{m}$ which represent the common starting point for all curves $[16,17]$.

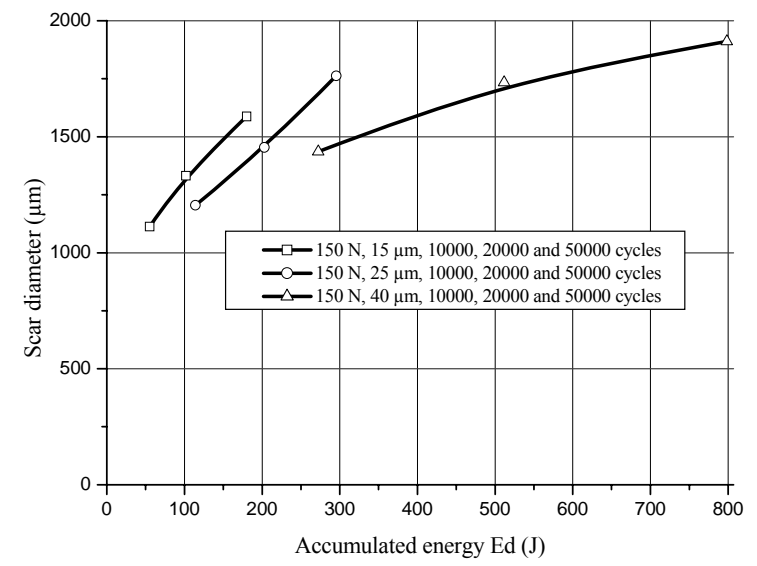

Fig. 8 Scar diameter according to cumulated energy $(\mathrm{J})$

Fig. 9 shows the wear trace morphology under the normal load of $150 \mathrm{~N}$. This figure shows clearly several concentric cracks according to an almost regular distribution in relation with the configuration of a plane/sphere contact. The grey area in top indicates an area rich in aluminum due to the accumulation of the aluminum debris whereas the majority of the trace presents a matter transfer coming from the steel ball, showing an important iron adhesion. 


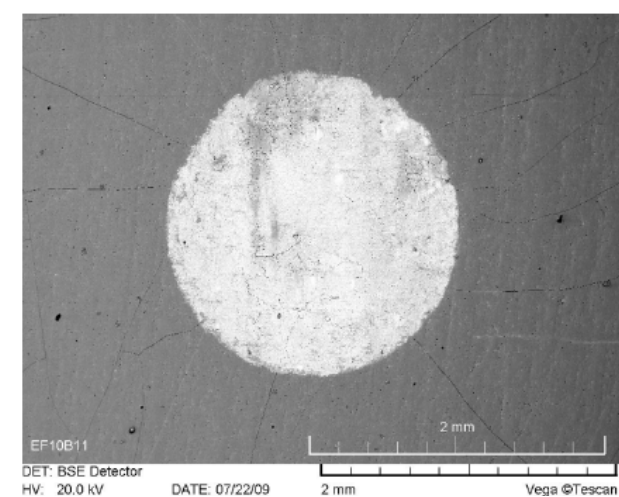

Fig. 9 MEB Observation of the scar under $150 \mathrm{~N}$ load

\section{Conclusion}

An experimental study was developed to analyze wear by fretting and predict life duration (lifetime duration) of the interface for a sphere/plane contact configuration for very thick layers. The fretting wear depends on the heterogeneous proprieties of coating and the wear rate remains closely related to the hardness and detachment of debris.

1. For low cycle number (low test duration up to 20000 cycles) the wear kinetics evolution induced by fretting is linear with an important removal of the upper layers that is related to the accommodation phenomenon of the displacement at the interface. The wear mechanism by adhesion is well-established.

3. For high cycle number (long test duration, 50000 cycles) a smooth increase is observed with the displacement amplitude and the kinetics evolution is parabolic.

4. The metal removal is an adhesive metal transfer mechanism and the metallic debris generated between fretted surfaces with flake-like morphology acts as a third body (powder) to soften wear like lubricant. However the hard and fragile thick layers present heterogeneity in mechanical proprieties with a high stress concentration that generate cracks during fretting loading at the contact.

\section{Acknowledgments}

The authors acknowledge the Laboratory of Tribology and Systems Dynamics (LTDS). Tests in this study were conducted using equipments of Bat. H10, Ecole Centrale de Lyon, France.

\section{References}

1. Holland, E.R, Li, Y., Abbott, P., Wilshaw, P.R. 2000. Large area gridded field emitter arrays using anodized alumina, Diplays 21: 99-104.

2. Bensalah, W., Elleuch, K., Feki, M., Ayedi, H.F. 2007. Optimisation of anodic layer proprieties on aluminium in mixed oxalic/sulphuric acid bath using statistical experiment, Surf coat Technol 201: 7855-7864.

3. Zhao, N.Q., Jiang, X.X., Shi, C.S., Li, J.J., Zhao, Z.G., Du, X.W. 2007. Effects of anodizing on anodic alumina structure, J. Mater Sci. 42: 3878-3882

4. Mezlini, S., Elleuch, K., Kapsa, Ph. 2006. The effect of sulphuric anodisation of aluminium alloys on contact problems, Surface and Coating Technology 200: 28522856.
5. Bensalah, W., Elleuch, K., Feki, M., De Petris-Wery, M., Ayedi, H.F. 2009. Mechanical failure of anodized film of aluminium in bending, J Mater and Design, doi:10.1016/j.matdes.2008.11.023.

6. Grzegorz, D. Sulka, Parkola, K.G. 2006. Anodising potential influence on nanostructures formed by anodization of aluminium in sulfuric acid, Thin Solid Films 515: 338-34.

7. Perier, V., Dieng, L., Gaillet, L., Tessier, C., Fouvry, S. 2009. Fretting-fatigue behaviour of bridge engineering cables in solution of sodium chloride, Wear 267: 308-314.

8. Sawae, Y., Murakami, T., Tashima, S., Shimotoso, T. 2001. Wear test of alumina-on-alumina sliding pairs as model experiment for wear in ceramic-on-ceramic joint prostheses, Tribology Research: 151-160.

9. Elleuch, K., Fouvry, S. 2002. Wear analysis of A357 aluminium alloy under fretting, Wear 253: 662-672.

10. Elleuch, K., Fouvry, S. 2005. Experimental and modeling aspect of abrasive wear of A357 aluminium alloy under gross slip fretting conditions, Wear 258: 40-49.

11. Vingsbo, O., Soderberg, S. 1998. On fretting maps, Wear, 126: 131-147

12. Elleuch, K., Fouvry, S., Kapsa, Ph. 2003. Fretting maps for anodized aluminium alloys, Thin Solid Films 426: 271-280.

13. Liu, Y., Asthana, R., Rohatgi, P. 1991. A map for wear mechanism in aluminium alloys, Wear 155: 99102.

14. Fouvry, S., Kapsa, Ph., Zahouani, H., Vincent, L. 1997. Wear analysis in fretting of hard coatings through a dissipated energy concept, Wear 203-204: 393-403.

15. Sproles, E.S., Duquette, D.J. 1978. The mechanism of material removal in fretting, Wear 49: 339-352.

16. Matlin, M., Kazankina, E., Kazankin, V. 2009. Mechanics of initial DOT contact, Mechanika 2(76): 2023.

17. Sari, M.R., Ville, F., Haiahem, A., Flamand, L. 2010. Effect of lubricant contamination on friction and wear in an EHL sliding contact, Mechanika 2(82): 4349.

A. Raid, N. Boualem, V. Fridrici, Ph. Kapsa

ANODINIMU APDOROTU STORU ALIUMINIO
SLUOKSNIŲ FRETINGINIO DILIMO POBŪDIS

R e zi u m è

Korpusinių detalių padengimas arba paviršiaus apdorojimas inžinerinėmis medžiagomis pagerina mechanines savybes ir atsparumą korozijai, tačiau nepagerina tribologinių savybių, pavyzdžiui, padengiant aliuminio lydiniais. Elementaria paviršiaus kontrole nustatomi paprasti parametrai, pavyzdžiui, šiurkštumas $R_{a}$. Šiame darbe trinties dilimo pobūdžiai nustatyti plokščiojo-sferinio kontakto (Al- $\mathrm{Al}_{2} \mathrm{O}_{3} /$ plienas) metodu, naudojant stiprų anodinima, buvo sudarytas labai storas aliuminio sluoksnis. Vertikalūs kietumo matavimai parodè sluoksnio storio nevienalytiškumą. Visi fretinginio dilimo bandymai buvo atlikti kambario temperatūroje didelio slydimo (Gros slip) režimu. Vidutinè trinties koeficiento vertè svyravo apie 1.1, ir 
skersmens kitimas nuo sukauptos energijos rodè bendrą didejjimą. Fretingo stebejjimai optiniu mikroskopu ir SEM parodè, kad dilimas kontakte yra aghezinis. Be to, nustatyta, kad dèl kietumo nevienalytiškumo susidaro dideli įtempiai storame sluoksnyje ir tai yra svarbiausia paviršiaus plastinès deformacijos su paviršiaus plyšių formavimosi priežastis.

\section{A. Raid, N. Boualem, V. Fridrici, Ph. Kapsa}

\section{WEAR FRETTING BEHAVIOR OF THICK HA ANODIZING ALUMINA LAYER}

\section{S u m m a ry}

It is common to coat a substrate, or provide surface treatment to engineering materials with good mechanical proprieties and resistance against corrosion but poor tribological proprieties as aluminium alloys. The sur- face control at a rudimentary level is reached through a simple parameter such as the roughness $\mathrm{Ra}$. In the present paper, very thick alumina layers were carried out by hard anodisation (HA) in order to determine the wear friction behavior with a plan-sphere contact $\left(\mathrm{Al}-\mathrm{Al}_{2} \mathrm{O}_{3} /\right.$ steel $)$ configuration. Profile hardness shows heterogeneous proprieties through layer thickness. All wear fretting tests were carried out at room temperature under Gross slip régime. The mean friction coefficient varies around the value 1.1 and the evolution of the diameter against cumulated energy shown a net increase. The observations by optical microscopy and SEM of the fretting scars at the contact indicate an adhesion wear phenomena. In addition the heterogeneity in hardness creates a high stress in the thick layer and represents the principal cause of the superficial plastic deformation and formation of surface cracks.

Received January 17, 2011 Accepted June 27, 2011 